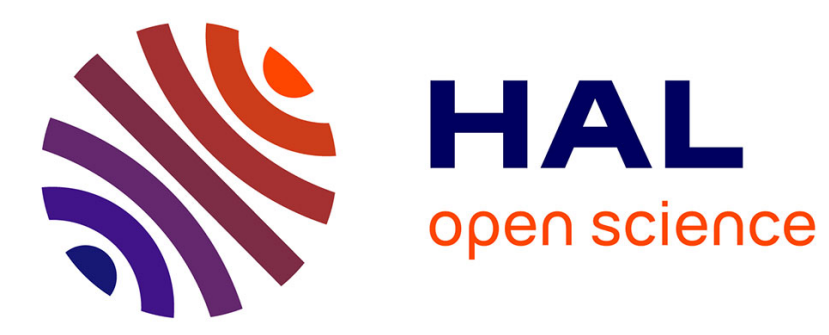

\title{
Multiphoton absorption in Er3+ doped fibres
}

Y. Ouerdane, A. Boukenter, M. Bouderbala, P. Ottavi, M. Druetta, E.

Maurice, G. Monnom

\section{To cite this version:}

Y. Ouerdane, A. Boukenter, M. Bouderbala, P. Ottavi, M. Druetta, et al.. Multiphoton absorption in Er3+ doped fibres. Journal de Physique IV Proceedings, 1994, 04 (C4), pp.C4-491-C4-494. 10.1051/jp4:19944118. jpa-00252568

\section{HAL Id: jpa-00252568 https://hal.science/jpa-00252568}

Submitted on 1 Jan 1994

HAL is a multi-disciplinary open access archive for the deposit and dissemination of scientific research documents, whether they are published or not. The documents may come from teaching and research institutions in France or abroad, or from public or private research centers.
L'archive ouverte pluridisciplinaire HAL, est destinée au dépôt et à la diffusion de documents scientifiques de niveau recherche, publiés ou non, émanant des établissements d'enseignement et de recherche français ou étrangers, des laboratoires publics ou privés. 


\title{
Multiphoton absorption in $\mathrm{Er}^{3+}$ doped fibres
}

\author{
Y. OUERDANE, A. BOUKENTER, M. BOUDERBALA, P. OTTAVI, M. DRUETTA, \\ E. MAURICE* and G. MONNOM*
}

Laboratoire Traitement du Signal et Instrumentation, URA 842 du CNRS, Faculté des Sciences et Techniques, 23 rue du Dr P. Michelon, 42023 Saint Etienne cedex 2, France

* Laboratoire Physique de la Matière Condensée, URA 190 du CNRS, Université de Nice Sophia Antipolis, Parc Valrose, 06108 Nice cedex 2, France

\begin{abstract}
We report the observation of green fluorescence from $\mathrm{Er}^{3+}$ doped Ge silica optical fibre pumped by a CW Titanium - Sapphire laser in the 840-975 $\mathrm{nm}$ range.

This emission is due to the multiphoton absorption and is attributed to the $\left({ }^{2} H_{11 / 2}+{ }^{4} S_{3 / 2}\right)$ decay level.

The evolution of this emission as a function of the wavelength excitation and the effect of power pump are discussed.
\end{abstract}

Optical fibres doped with erbium ions have been developed for use as both optical amplifiers and laser [1-4]. They are known to fluoresce at shorter wavelengths than the pump wavelength.

We studied the green fluorescence of the $\mathrm{Er}^{3+}$ doped fibres when they are pumped by a $\mathrm{CW}$ titanium-Sapphire laser in the $840-975 \mathrm{~nm}$ range with $30 \mathrm{~mW}$ injected power. The used fibre was $3 \mathrm{~m}$ length and $5 \mu \mathrm{m}$ in diameter.

The guided light emission at the end of the fibre is focused on the entrance slit of the double Czerny turner monochromator equipped with two $1800 \mathrm{l} / \mathrm{mm}$ gratings and at the exit slit we used a cooled $6256 \mathrm{~S}$ photomultiplier as a detector.

In the bulk crystal lasers [5-6], erbium ions are excited into the upper laser level predominantly through an ion-ion interaction between ions residing in the ${ }^{4} I_{11 / 2}$ manifold. However, in the lightly doped germanosilicate fibre used during these experiments $(\approx 70-100 \mathrm{ppm})$, ion-ion interactions are negligible, and the dominant excitation mechanism is attributed to the excited state absorption (ESA) of pump photons. Figure 1 represents the energy levels of the trivalent erbium ions with the relevant green transition between $\left({ }^{4} S_{3 / 2}+{ }^{2} \mathrm{H}_{11 / 2}\right)$ level and the ${ }^{4} I_{15 / 2}$ ground state.

Our range excitation energy allows us to populate, by the absorption of pump photons, the ${ }^{4} I_{11 / 2}$ band. Some of these excited ions then branch into the ${ }^{4} I_{13 / 2}$ level. The ions are then further excited by pump photons essentially into the ${ }^{4} \mathrm{~F}_{3} / 2$ and ${ }^{2} \mathrm{H}_{11 / 2}$. Furthermore, by a nonradiative decay, the ${ }^{4} \mathrm{~F}_{3 / 2}$ band populates the ${ }^{2} \mathrm{H}_{11 / 2}$ level. Generally, a large proportion of the ions in these higher energy levels then relax into the ${ }^{4} S_{3 / 2}$ level from which a direct transition to the ground state is responsible for the green emission.

The evolution of the green emission as a function of the excitation energy (fig. 2) presents a "resonance pic" at $\approx 11800 \mathrm{~cm}^{-1}(847.5 \mathrm{~nm})$ which corresponds exactely to the energy gap between the ${ }^{4} S_{3 / 2}$ and ${ }^{4} I_{13 / 2}$ levels. Whereas this emission completely disappears when we use a $910 \mathrm{~nm}$ excitation wavelength. So, if the ${ }^{4} I_{11 / 2}$ level was populated during the first stage we 
should always be able to observe this green luminescence which is not however the case and consequently this leads to quite a high transfert from the ${ }^{4} I_{11 / 2}$ level to the metastable ${ }^{4} I_{13 / 2}$ level.

Whereas, Peter A. Krug and al. [7] explain the green luminescence observed in their experiments by a preferential population of the ${ }^{4} I_{11 / 2}$ level and not of the ${ }^{4} I_{13 / 2}$ level when they excite their fibre at $980 \mathrm{~nm}$ with a very strong power ( $u$ p to $255 \mathrm{~mW}$ is injected). This shows how these two mechanisms are strongly correlated to the laser power injected in the fibre.

The good resolution of the whole spectra (fig. 3) from $515 \mathrm{~nm}$ to $565 \mathrm{~nm}$ clearly shows a structure which can be attributed to the different Stark components of the $\left({ }^{2} \mathrm{H}_{11 / 2}+{ }^{4} \mathrm{~S}_{3 / 2}\right) \rightarrow{ }^{4} \mathrm{I}_{15 / 2}$ transition.

The $538 \mathrm{~nm}$ line intensity is strongly dependent on the energy excitation variation and it exactly follows the resonnance curve in fig. 2 .

Even when the energy excitation decreases, a red luminescence (not shown in fig. 3) is still present at about $620 \mathrm{~nm}$ despite the low quantum efficiency of our photomultiplier. Hence, we populate the ${ }^{4} \mathrm{~F} 9 / 2$ level which desexcites to the ground state ${ }^{4} I_{15 / 2}$.

At low temperature $(77 \mathrm{~K})$, in addition to the narrowing of the emission lines we observe at 538 $\mathrm{nm}$ a strong effect on the line which is strongly assisted by the phonons.

The type of multiphoton processes studied by $J$. Thogersen and al [8] which enable reaching the higher excited states such as ${ }^{4} \mathrm{G}_{11 / 2}$ and ${ }^{2} \mathrm{H}_{9 / 2}$ do not exist in our experiment because in our spectra no blue luminescence corresponding to the ${ }^{2} \mathrm{H}_{9 / 2} \rightarrow{ }^{4} \mathrm{I}_{15 / 2}$ transition is present.

This permits us to clarify and understand the excitation processes involved in this $\mathrm{Er}^{3+}$ dopedfibre.

\section{REFERENCES}

[1] Whitley T.J., Millar C.A., Wyatt R., Brierley M.C. and Szebesta D.

Electron. Lett. 27 (20) 1785 (1991)

[2] Barnes W.L., Poole S.B., Townsend J.E., Reekie L., Taylor D.J. and Payne D.N. Journal of Lightwave Technologie, 7, 10, 1461 (1989)

[3] Allain J.Y., Monerie M. and Poignant $H$.

Electron. Lett. 2 (28) 111 (1992)

[4] Desurvire E., Simpson J.R. and Becker P.C.

Optics lett. 12, 11, 888 (1987)

[S] Macfarlane R.M.

Appl. Phys. Lett. 54, 23, 2301 (1989)

[6] Hebert T., Wannemacher R., Lenth W. and Macfarlane R.M.

Appl. Phys. Lett. 57, 17, 1727 (1990)

[7] Krug Peter A., Sceats Mark G., Atkins G.R., Guy S.C. and Poole S.B.

Optics Lett. 16, 24, 1976 (1991)

[8] Thogersen J., Bjerre N. and Mark J.

Optics lett. 18, 3, 197 (1993) 


\section{C4-493}

Energy $\left(\mathrm{cm}^{-1}\right)$

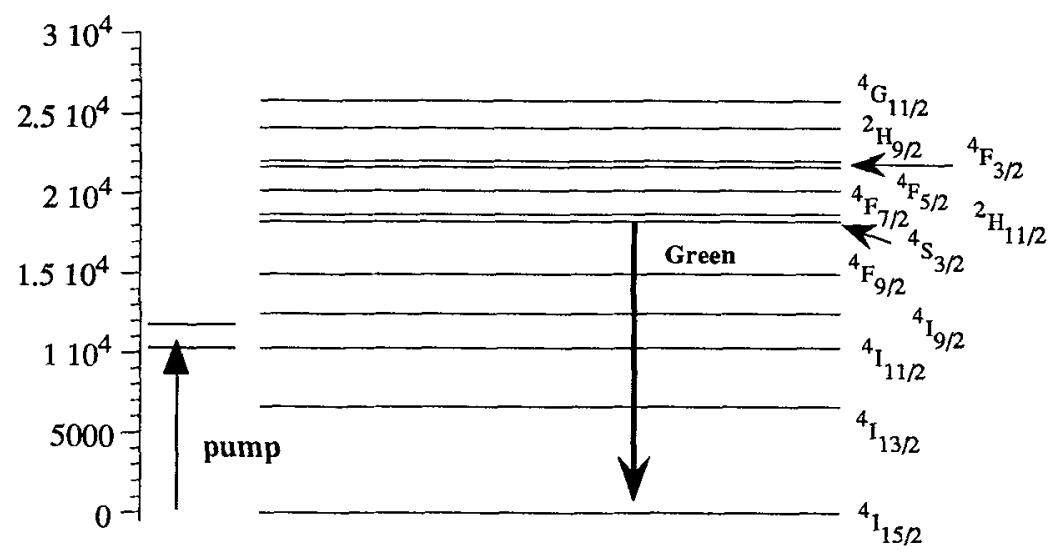

Fig. 1 Energy-diagram of the Erbium trivalent ions $\mathrm{Er}^{3+}$

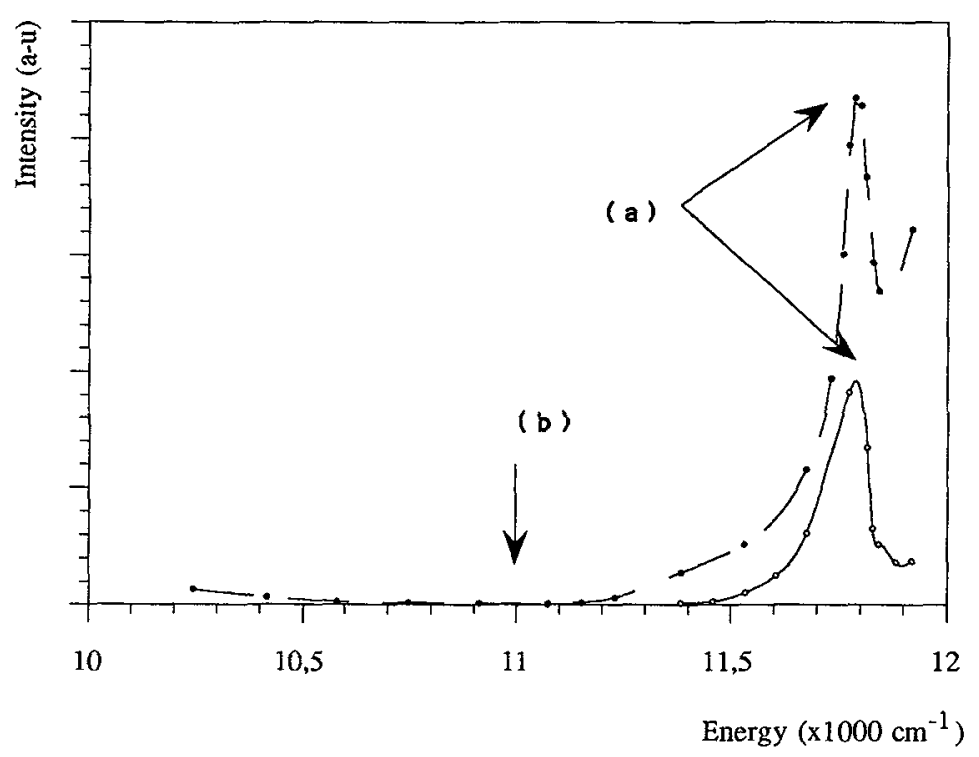

Fig. 2 Evolution of the integrated green luminescence as a function of the energy excitation. The curve presents a resonance at $846 \mathrm{~nm}$ wavelength excitation (a) and there's no signal at $910 \mathrm{~nm}(\mathrm{~b})$. The experiment was performed at two different temperatures $(\bullet 300 \mathrm{~K}$ and $077 \mathrm{~K})$. 


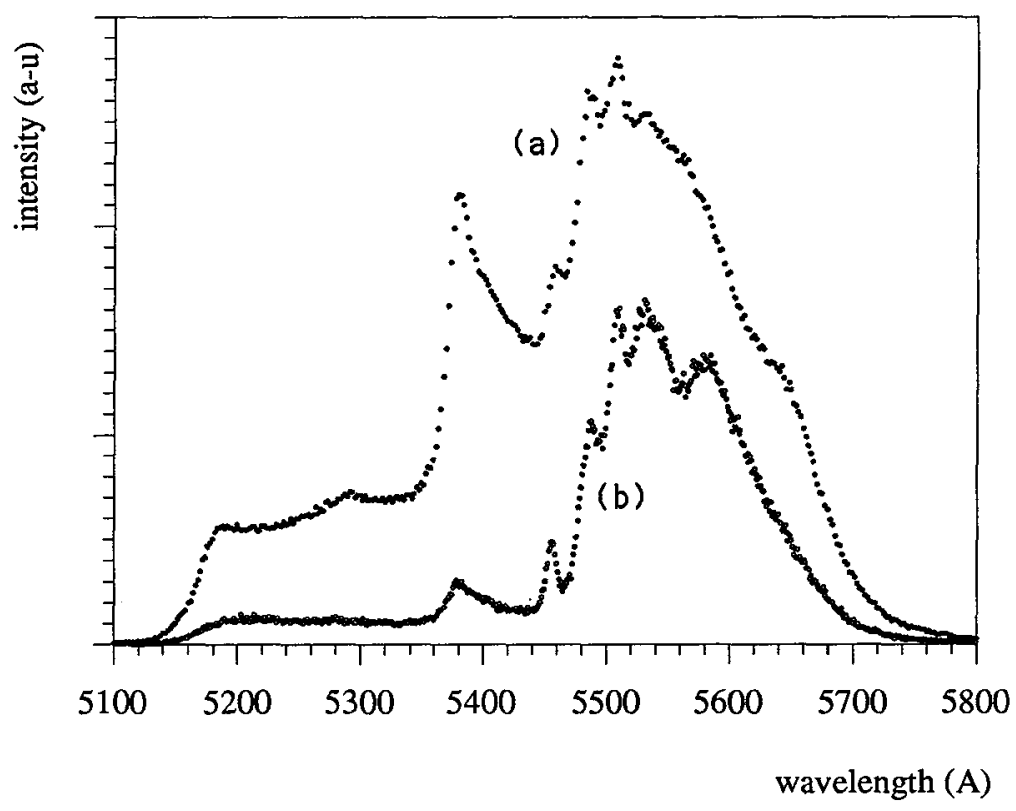

Fig. 3 Emission spectra of the guided fluorescence of $\mathrm{Er}^{3+}$ doped-fibre at $846.5 \mathrm{~nm}$ wavelength excitation (a: $300 \mathrm{~K}, \mathrm{~b}: 77 \mathrm{~K}$ ) 